\title{
The Clinically Used Iron Chelator Deferasirox is an Inhibitor of Epigenetic JumonjiC Domain-Containing Histone Demethylases
}

Manfred Jung, Martin Roatsch, Inga Hoffmann, Martine I. Abboud, Rebecca L. Hancock, Hanna Tarhonskaya, Kuo-Feng Hsu, Sarah E. Wilkins, Tzu-lan Yeh, Kerstin Lippl, Kerstin Serrer, Isabelle Moneke, Theresa D. Ahrens, Dina Robaa, Sandra Wenzler, Henriette Franz, Wolfgang Sippl, Silke Lassmann, Sven Diederichs, Erik Schleicher, Christopher J. Schofield, Akane Kawamura, Roland Schüle

Submitted date: 09/07/2019 - Posted date: 09/07/2019

Licence: CC BY-NC-ND 4.0

Citation information: Jung, Manfred; Roatsch, Martin; Hoffmann, Inga; Abboud, Martine I.; Hancock, Rebecca L.; Tarhonskaya, Hanna; et al. (2019): The Clinically Used Iron Chelator Deferasirox is an Inhibitor of Epigenetic JumonjiC Domain-Containing Histone Demethylases. ChemRxiv. Preprint.

$\mathrm{Fe}(\mathrm{II})$ - and 2-oxoglutarate (2OG)-dependent JumonjiC domain-containing histone demethylases (JmjC $\mathrm{KDMs}$ ) are epigenetic eraser enzymes involved in the regulation of gene expression and are emerging drug targets in oncology. We screened a set of clinically used iron chelators and report that they potently inhibit JMJD2A (KDM4A) in vitro. Mode of action investigations revealed that one compound, deferasirox, is a bona fide active site-binding inhibitor as shown by kinetic and spectroscopic studies. Synthesis of derivatives with improved cell permeability resulted in significant upregulation of histone trimethylation and potent cancer cell growth inhibition. Deferasirox was also found to similarly inhibit human 2OG-dependent hypoxia inducible factor prolyl hydroxylase activity. Therapeutic effects of clinically used deferasirox may thus involve transcriptional regulation through $20 \mathrm{O}$ oxygenase inhibition. Deferasirox may provide a useful starting point for the development of novel anticancer drugs targeting 2OG oxygenases and a valuable tool compound for investigations of KDM function.

File list (2)

MANUSCRIPT changes accepted.pdf (2.83 MiB) view on ChemRxiv • download file SUPPORTING INFORMATION changes accepted with ... (12.17 MiB) view on ChemRxiv • download file 
Other files

MANUSCRIPT changes accepted.pdf (2.83 MiB)

view on ChemRxiv • download file

SUPPORTING INFORMATION changes accepted with ... (12.17 MiB) view on ChemRxiv • download file 